\title{
Effect of dry-salt processing on the textural properties and cell wall polysaccharides of cv. Thasos black olives
}

\author{
Susana M Cardoso, ${ }^{1,2}$ Isabel Mafra, ${ }^{1,3}$ Ana Reis, ${ }^{1}$ Dominique MR Georget, ${ }^{4,5}$ \\ Andrew C Smith, ${ }^{4}$ Keith W Waldron ${ }^{4}$ and Manuel A Coimbra ${ }^{1 *}$
}

\begin{abstract}
BACKGROUND: Thasos is an olive variety cultivated mainly in Greece used to produce 'naturally black dry-salted olives'. This process consists in placing the olives in disposed layers with coarse sodium chloride. The loss of water and other solutes gradually debitters and wrinkles the fruits. In this study, the effect of dry-salt processing on the texture and cell wall polysaccharide composition was investigated.

RESULTS: This type of processing affected primarily the mechanical properties of the olive flesh. In processed olives, this tissue was approximately 4.5 times stronger and also more deformable up to failure and stiffer than that from the raw olives. The dry-salt processing had its strongest effect on pectic polysaccharides. This included the increment of solubilization of arabinose-rich polymers in aqueous solutions, and thus their partial loss to the soak medium during dry-salting. Contrarily, galacturonic acid-rich polymers were further retained in the processed olives, probably by their stabilization within the cell walls by reduction of the electrostatic repulsion between the acidic groups of these polysaccharides due to sodium ions.
\end{abstract}

CONCLUSION: The texture improvement of olive flesh by dry-salt processing seems to be correlated with the reorganization of the galacturonic acid-rich pectic polysaccharides into the cell wall of the fruit.

Keywords: cell wall composition; processing; table olives; Thasos; mechanical properties

\section{Introduction}

Since ancient times, olives (Olea europaea L.) have been prepared for human consumption. Currently, this popular product is primarily produced by three main types of processes: alkali-treated and fermented Spanish style green olives; naturally fermented black olives (Greek style); and alkali-treated and oxidized black olives (Californian style). Besides those, other traditionally processed table olives can also be found in the marketplace according to local consumers' demands.

Thasos is a variety of olive cultivated mainly on the island of Thasos in northern Greece. From this, a special type of naturally black olives called 'naturally black dry-salted olives Thasos style' is prepared. This particular type of olive is appreciated not only in Greece but also in other Mediterranean countries such as Algeria and Morocco. Olives are harvested in December when fully mature and completely black in colour. The traditional processing method consists in placing the olives in concrete tanks as disposed layers with coarse sodium chloride in a proportion of 40 parts of salt to 100 parts of olives (w/w). Due to the high osmotic pressure exerted by the salt, olives lose water and other solutes, including much of the bitter agent oleuropein, and become gradually debittered and wrinkled (dry-salt processing). ${ }^{1,2}$ So far, this process has been carried out empirically, taking 30-60 days of dry-salt for olives to be ready for consumption. Dry-salted olives have been reported to have a water activity of $0.75-0.85, \mathrm{pH}$ of $4.5-5.5$, oil content of $35-39 \%$, water content of $30-35 \%$, $2-3 \%$ reducing sugars and sodium chloride content of $4-10 \%$ of the flesh. ${ }^{2}$ The low water activity/high salt content of the product can ensure its microbiological safety during storage. ${ }^{2}$

Texture is one of the organoleptic properties most affected by processing the olives. The use of sodium ions has been shown to influence the texture of the fruit differently, depending on the processing

\footnotetext{
${ }^{1}$ Departamento de Química, Universidade de Aveiro, 3810-193 Aveiro, Portugal

${ }^{2}$ Escola Superior Agrária de Bragança, Instituto Politécnico de Bragança, 5301-855 Bragança, Portugal

${ }^{3}$ Escola Superior de Biotecnologia, Universidade Católica Portuguesa, Rua Dr. António Bernardino de Almeida, 4200-072 Porto, Portugal

${ }^{4}$ Institute of Food Research, Norwich Laboratory, Colney, Norwich NR4 7UA, UK

${ }^{5}$ University of East Anglia, School of Chemical Sciences and Pharmacy, Norwich NR4 7TJ, UK
} 
conditions, such as the $\mathrm{pH}$ and the concentration of the salt. ${ }^{3}$ The majority of the bibliographic data on this subject concerns olives in brine, usually produced by maintaining the fruits in a solution of $40-120 \mathrm{~g} \mathrm{~L}^{-1}$ sodium chloride for several months. In this context, Jiménez et al. ${ }^{4}$ showed that green Spanish olives had a significant texture increase when brining was performed after lye treatment ( $\mathrm{pH}$ of flesh 11-12), but this effect was minimal when brining was carried out after the fermentation of the fruit $(\mathrm{pH} \mathrm{3-4).} \mathrm{For}$ black olives, texture improvement after brining has been reported for the Hojiblanca variety undergoing the Californian process. ${ }^{5}$ The same trend was observed in naturally black olives of the Conservolea variety, by changing the sodium chloride concentration of the brine solution from 40 to $60 \mathrm{~g} \mathrm{~L}^{-1}$, and the opposite behaviour was obtained for higher sodium concentrations $\left(80 \mathrm{gL}^{-1}\right){ }^{6}$ Despite those reports, olives undergoing dry-salt processing, being subjected to distinctly different conditions compared to those usually applied in brine, were never studied for their mechanical properties.

As generally accepted, the texture of the fruits is mainly dependent on their cell wall vigour, ${ }^{7}$ and thus changes in this physical property are associated with modifications in cell wall polysaccharides. Up to now, studies on this subject have mainly focused on pectic polysaccharides. ${ }^{8-11}$ However, as the other polysaccharides from the cell walls can also be affected by the industrial processing, ${ }^{12-14}$ these polymers should also be investigated.

Previous studies on fresh olives of Thasos variety have described its free sugar and polyol composition, ${ }^{15}$ and its biophenolic profile. ${ }^{16,17}$ The aim of the present work is to further characterize this olive variety, providing information about the mechanical properties and cell wall composition. The same features will also be described for the processed olives, in order to understand the influence of dry-salt processing in these physicochemical properties of the Thasos olives, which are critical for determining the quality of the final product.

\section{Materials and Methods}

\section{Plant materia}

Olive fruits (Olea europaea L. cv. Thasos) at the mature black stage were supplied by the Association of Olive Growers of Thasos island directly after harvest. The fruits were hand selected, washed thoroughly under tap water and left to dry. Dry-salt processing was performed on a pilot scale as described by Panagou, ${ }^{2}$ by packing the fruits $(100 \mathrm{~kg})$ in a large PVC drum (220 L) with $40 \mathrm{~kg}$ of uniformly dispersed coarse salt, covered with a top layer of approximately $2 \mathrm{~cm}$ of salt. During the dry-salting, water and other solutes lost by the olives were removed from the bottom of the drum.

\section{Evaluation of mechanical properties}

Tensile properties were assessed for the skin and flesh of olive fruit, either untreated or processed. Specimens of both tissues with a well-defined geometry were prepared: a quarter of the whole skin was peeled from each fruit and a strip $5 \mathrm{~mm}$ wide and approximately $20 \mathrm{~mm}$ long was cut. The thickness varied from 0.05 to $0.3 \mathrm{~mm}$. The width of the flesh strips was in the range $1-2 \mathrm{~mm}$. Both skin and flesh strips were notched on one side to a depth of $2.5 \mathrm{~mm}$. The edges of the strips were glued to two metal plates using cyanoacrylate (Eurobond Adhesive Ltd, Sittingbourne, UK), to leave a $14 \mathrm{~mm}$ gap between the two plates, which defined the sample length. The high-deformation mechanical properties of the olive strips (skin and flesh) were measured using a universal testing machine (texture analyser model TAXT2, Stable Microsystems, Godalming, UK) with a $5 \mathrm{~kg}$ load cell. The apparatus was used in tension mode with a test speed of $0.05 \mathrm{~mm} \mathrm{~s}^{-1}$. Ten replicates were tested. Various engineering parameters characterizing the specimens were calculated on the basis of the logged force-displacement curve:

- strength $=$ force at failure/unnotched cross-sectional area;

- strain at failure = change in length/original length;

- stiffness = slope of linear region of force - displacement curve normalized by unnotched crosssectional area and original length, respectively.

Preparation of cell wall material (CWM)

CWM was prepared according to the method described by Coimbra et al., ${ }^{18}$ with some changes to allow the use of the largest possible number of samples and to avoid the use of phenol reagent. ${ }^{19}$ Olives were destoned on arrival and kept at $-20^{\circ} \mathrm{C}$ until used. Olive pulps were homogenized and triturated in $15 \mathrm{~g} \mathrm{~L}^{-1}$ sodium dodecyl sulfate solution (SDS) containing $5 \mathrm{mmol} \mathrm{L}^{-1}$ sodium metabisulfite and the resultant material was filtered and washed with $5 \mathrm{~g} \mathrm{~L}^{-1}$ SDS solution containing $3 \mathrm{mmol} \mathrm{L}^{-1}$ sodium metabisulfite. The residue was washed with water, extracted with a solution of 1-propanol-acetic acid-water (PrAW, 2:1:1 v/v/v), washed again with water and freeze dried to give the CWM. All the extracts obtained during CWM preparation were analyzed separately, but the data were condensed as follows: the first three extracts $\left(15 \mathrm{~g} \mathrm{~L}^{-1} \mathrm{SDS}, 5 \mathrm{~g} \mathrm{~L}^{-1}\right.$ SDS and water wash) were named 'SDS extract', and those obtained by PrAW and the following water wash were named 'PrAW extract'.

\section{Sequential extraction of CWM}

CWM was extracted according to the method described by Mafra et al. ${ }^{19}$ CWM (approximately $10 \mathrm{~g}$ ) was sequentially extracted with: (1) $0.5 \mathrm{~mol}$ $\mathrm{L}^{-1}$ imidazole-HCl (pH 7.0), for $16 \mathrm{~h}$ at $20{ }^{\circ} \mathrm{C}$; (2) $0.5 \mathrm{~mol} \mathrm{\textrm {L } ^ { - 1 }}$ imidazole- $\mathrm{HCl}$ ( $\mathrm{pH}$ 7.0), for $2 \mathrm{~h}$ at $20^{\circ} \mathrm{C}$; (3) $50 \mathrm{mmol} \mathrm{L}^{-1} \mathrm{Na}_{2} \mathrm{CO}_{3}+$ $20 \mathrm{mmol} \mathrm{L}^{-1} \mathrm{NaBH}_{4}$, for $16 \mathrm{~h}$ at $4{ }^{\circ} \mathrm{C}$; (4) $50 \mathrm{mmol}$ $\mathrm{L}^{-1} \mathrm{Na}_{2} \mathrm{CO}_{3}+20 \mathrm{mmol} \mathrm{L}^{-1} \mathrm{NaBH}_{4}$, for $2 \mathrm{~h}$ at $20^{\circ} \mathrm{C}$; (5) $0.5 \mathrm{~mol} \mathrm{~L}^{-1} \mathrm{KOH}+20 \mathrm{mmol} \mathrm{L}^{-1} \mathrm{NaBH}_{4}$, for $2 \mathrm{~h}$ 
at $4{ }^{\circ} \mathrm{C}$; (6) $1 \mathrm{~mol} \mathrm{~L}^{-1} \mathrm{KOH}+20 \mathrm{mmol} \mathrm{L}^{-1} \mathrm{NaBH}_{4}$, for $2 \mathrm{~h}$ at $4^{\circ} \mathrm{C}$; (7) $1 \mathrm{~mol} \mathrm{~L}{ }^{-1} \mathrm{KOH}+20 \mathrm{mmol} \mathrm{L}^{-1}$ $\mathrm{NaBH}_{4}$, for $2 \mathrm{~h}$ at $20^{\circ} \mathrm{C}$; (8) $4 \mathrm{~mol} \mathrm{~L} \mathrm{~L}^{-1} \mathrm{KOH}+$ $20 \mathrm{mmol} \mathrm{L}^{-1} \mathrm{NaBH}_{4}$, for $2 \mathrm{~h}$ at $20^{\circ} \mathrm{C}$; and (9) $4 \mathrm{~mol} \quad \mathrm{~L}^{-1} \mathrm{KOH}+35 \mathrm{~g} \mathrm{~L}^{-1} \mathrm{H}_{3} \mathrm{BO}_{3}+20 \mathrm{mmol} \mathrm{L}^{-1}$ $\mathrm{NaBH}_{4}$, for $2 \mathrm{~h}$ at $20^{\circ} \mathrm{C}$. The residue obtained after the alkali extractions was suspended in water, acidified ( $\mathrm{pH} 5-6)$ and dialyzed. The supernatant from dialysis of the alkali extracted residue (sn-CR) was collected separately from the residue (cellulosic residue, CR) by centrifugation and filtration. After dialysis, all extracts were concentrated under reduced pressure and freeze dried.

\section{Carbohydrate analysis}

Neutral sugars were released by Saeman hydrolysis, comprising a $3 \mathrm{~h}$ pre-hydrolysis step with $11 \mathrm{~mol}$ $\mathrm{L}^{-1} \mathrm{H}_{2} \mathrm{SO}_{4}$ at room temperature and hydrolysis at $100{ }^{\circ} \mathrm{C}$ with $1 \mathrm{~mol} \mathrm{~L}^{-1} \mathrm{H}_{2} \mathrm{SO}_{4}{ }^{20}$ and analyzed as their alditol acetates by gas chromatography ${ }^{21,22}$ using a Carlo Erba 6000 chromatograph (Carlo Erba, Milan, Italy) with a split injector (split ratio $1: 60$ ) and a flame ionization detector. A $30 \mathrm{~m}$ column DB-225 (J\&W Scientific, Folsom, CA, USA) with i.d. $0.25 \mathrm{~mm}$ and $0.15 \mu \mathrm{m}$ film thickness was used. The injector and detector temperatures were 220 and $230{ }^{\circ} \mathrm{C}$, respectively. The oven temperature programme used was: $220^{\circ} \mathrm{C}$ for $4 \mathrm{~min}$, followed by $230^{\circ} \mathrm{C}$ for $6.5 \mathrm{~min}$, at a rate of $25^{\circ} \mathrm{C} \mathrm{min}^{-1}$. The flow rate of the carrier gas $\left(\mathrm{H}_{2}\right)$ was set at $1 \mathrm{~mL} \min ^{-1}$ at $220^{\circ} \mathrm{C}$. Cellulosic glucose was calculated as the difference between the content found with and without $\mathrm{H}_{2} \mathrm{SO}_{4}$ pre-hydrolysis. Uronic acids (UrAc) were determined colorimetrically according to a modification of the method of Blumenkrantz and Asboe-Hansen. ${ }^{23}$

The hydrolysis of all samples was done in duplicate and each one was injected twice. Results with less than $5 \%$ of variability in the major component cell wall sugars were obtained. A third analysis was done for those few samples with higher variability.

Cell wall polysaccharide composition estimates of the olive pulp were based on known data for the different polysaccharide constituents of olive pulp cell walls for Douro variety, obtained by methylation analysis, ${ }^{24}$ ${ }^{13} \mathrm{C}$ nuclear magnetic resonance ${ }^{25}$ and Fourier transform infrared spectroscopy. ${ }^{26}$ All the extracts resulting from CWM preparation and sequential extraction were used for this calculation. Pectic polysaccharides were estimated from the sum of UrAc, Ara (arabinose), Gal (galactose) and Rha (rhamnose) present in all the extracts, with correction for UrAc because of the occurrence of glucuronoxylans in $\mathrm{KOH}$ extracts and $\mathrm{CR}$, and of $\mathrm{Gal}$ in xyloglucan-rich $\mathrm{KOH}$ extracts. Glucuronoxylans were estimated based on Xyl (xylose) and UrAc amounts, with correction for Xyl from xyloglucans and UrAc from pectic polysaccharides. Xyloglucans were obtained from the sum of Glc (glucose) in non-cellulosic extracts (including Glc from $\mathrm{CR}$ after $1 \mathrm{~mol} \mathrm{~L}^{-1} \mathrm{H}_{2} \mathrm{SO}_{4}$ hydrolysis), the calculated amount of Xyl attributed to xyloglucans, Fuc (fucose) and the contribution of Gal. Mannans were estimated according to the amount of Man (mannose). The Ara present in $4 \mathrm{~mol} \mathrm{~L}^{-1} \mathrm{KOH}$ extracts belonged either to pectic polysaccharides or Ara-rich glycoproteins. According to Coimbra et al., ${ }^{24}$ the amount of Ara from glycoproteins in these extracts accounts for $60 \%$ of the total Ara. This proportion was assumed for the purpose of estimating the amount of Ara-rich glycoproteins and pectic polysaccharides. The amount of cellulose was estimated according to the Glc remaining after $1 \mathrm{~mol} \mathrm{~L}^{-1} \mathrm{H}_{2} \mathrm{SO}_{4}$ hydrolysis in CR.

\section{Moisture content}

Moisture content of the olive pulp was determined in triplicate by oven drying $5 \mathrm{~g}$ of crushed olive pulp at $102 \pm 2{ }^{\circ} \mathrm{C}$ for $4 \mathrm{~h}$, plus $2 \mathrm{~h}$ to confirm weight stabilization.

\section{Results and Discussions}

\section{Mechanical properties}

Table 1 summarizes the mechanical properties of the skin and of the flesh from the raw and drysalted olives. As observed, the two tissues showed divergent texture features, in accordance with their typical composition. The skin of the olive is mainly composed of a unique layer of parenchyma cells, covered by several wax-rich cuticular layers, while the flesh is a parenchymatous tissue with thin walls that are rich in pectic polysaccharides, hemicelluloses and cellulose. The differences in structure and the cell wall composition of these tissues, as well as the turgor pressure of the cells, contribute to their specific mechanical properties.

The strength of the skin and of the flesh from raw olives was similar to that described for black olives of the Hojiblanca ${ }^{27}$ variety, and rather stronger than that of the Douro variety. ${ }^{27}$ Moreover, the data in Table 1 indicate that the dry-salting process mainly affected the strength of the olive flesh, raising it by approximately

Table 1. Mechanical properties of skin and flesh tissues from raw and dry-salted olives cv. Thasos

\begin{tabular}{lcccr}
\hline & \multicolumn{2}{c}{ Skin } & & \multicolumn{2}{c}{ Flesh } \\
\cline { 2 - 5 } & Raw & Dry-salted & Raw & Dry-salted \\
\cline { 2 - 5 } & $1.81 \pm 0.35$ & $2.03 \pm 0.79$ & $0.013 \pm 0.002$ & $0.059 \pm 0.013$ \\
Strength (MPa) & $0.086 \pm 0.005$ & $0.116 \pm 0.015$ & $0.092 \pm 0.019$ & $0.259 \pm 0.021$ \\
Strain at failure & $43.3 \pm 15.3$ & $30.6 \pm 4.2$ & $0.139 \pm 0.027$ & $0.199 \pm 0.038$ \\
Stiffness (MPa) & & &
\end{tabular}

Values are mean \pm standard error. 
4.5 times. This fact is probably a consequence of the loss of turgidity and also modification of the cell wall composition. Brining is also known to increase olive flesh strength but also decreases skin strength. ${ }^{5}$ The primary influence of sodium in the olive flesh strength as compared to that on the skin was previously documented for black olives of the Conservolea variety on treatment in brine solutions, ${ }^{6}$ but to our knowledge there are no published data on the strength variation of olive tissues after dry-salt processing.

The strain at failure for the skin and the flesh of the raw Thasos olives were of the same order of magnitude as those of the Hojiblanca and Douro varieties, ${ }^{27}$ although slight differences were observed. More specifically, as compared to the above fruits at the same ripening stage, the olive skin and the flesh of Thasos were, respectively, the most and the lesser deformable. The processing of Thasos olives greatly increased the strain at failure of the flesh, while almost no effect was registered for this property in the skin. According to this, upon dry-salting the flesh became twice as deformable when it fails. These figures are in accordance with the results described by Georget et al., ${ }^{5}$ for black Hojiblanca olives after brine treatment with a $40 \mathrm{~g} \mathrm{~L}^{-1}$ sodium chloride solution for 2 months.

The skin of the raw Thasos olives was approximately 300 times stiffer than the flesh of the fruit (Table 1). In comparison to other olive fruits at the same ripening stage, the stiffness of the Thasos olive skin was higher than that of the Hojiblanca and Douro varieties (approximately $20 \mathrm{MPa}){ }^{27}$ Also, the flesh of raw Thasos olives was about twice as stiff as the above varieties. ${ }^{27}$ Further to the dry-salt processing, the stiffness of the flesh of Thasos olives was increased. This behaviour, however, contrasts with the stiffness decrease observed for the olive flesh of Hojiblanca variety upon brining treatment. ${ }^{5}$

\section{Cell wall polysaccharide analysis}

Raw black olives of Thasos variety had a low moisture content $(45.4 \%)$ when compared to other olive varieties at the same ripening stage, namely the Portuguese Douro variety $(61 \%)^{19}$ and the Spanish varieties of Ascolano, Manzanilla, Mission and Sevillano $(52-67 \%){ }^{28}$ After dry-salting, the moisture of the fruits reached a value of $26.1 \%$. Thus, considering the disparity of the moisture content of the raw and the dry-salted olives, the yields of the extracts in Table 2 were expressed on a dry pulp basis to allow a more direct comparison with the amount of material extracted. The yield of CWM changed from $9.1 \%$ in raw olives to $8.4 \%$ after processing, suggesting that this treatment prompted the solubilization of some polymeric material into the soak medium. For the olive fruits of Thasos, the total amount of polysaccharides in the CWM (calculated by multiplying the yield in polymeric material by the total sugars in fractions on a $\mathrm{g} \mathrm{kg}^{-1}$ basis) and noncarbohydrate components decreased $14 \%$ and $5 \%$ after processing, respectively. These results indicate that under the dry-salting conditions used the cell wall carbohydrates were solubilized to a greater extent than the non-carbohydrate material. According to data in Table 2, a significant part of these polysaccharides was recovered in the SDS extracts of dry-salted olives, as the yield and total sugars of this fraction clearly increased when compared to that from raw olives. The sugar composition of the SDS extracts of dry-salted olives shows an increase in the relative proportion of UrAc and Ara (Table 2), suggesting that dry-salting primarily solubilized the Ara-rich pectic polysaccharides of the fruit.

The major sugars present in the CWM of the olive Thasos variety were Glc (43 mol\%), Xyl (22 mol\%), UrAc and Ara (14 mol\%). Man, Gal and Rha occurred only as minor constituents. In the CWM of drysalted olives, the relative proportion of UrAc and Glc was increased and that of $\mathrm{Xyl}$ and Ara was diminished. Variation in the proportion of UrAc and Ara from 1:1 in raw olives to 2:1 in dry-salted olives suggested that the pectic polysaccharides recovered in the CWM extract from the processed olive fruits were less branched. Non-cellulosic glucose accounted for $20-22 \%$ of the total glucose quantified.

\section{Fractionation of CWM}

The CWM polysaccharides of the raw and drysalted olives of Thasos variety were sequentially extracted with aqueous solutions of imidazole, $\mathrm{Na}_{2} \mathrm{CO}_{3}$ and $\mathrm{KOH}$ of increasing strength to leave a final cellulosic-rich residue, as described in the Experimental section. This procedure gave

Table 2. Sugar composition of SDS and PrAW extracts and of cell wall material from raw and dry-salted olive pulp of Thasos

\begin{tabular}{|c|c|c|c|c|c|c|c|c|c|c|c|}
\hline \multirow[b]{2}{*}{ Sample } & \multirow[b]{2}{*}{ Fraction } & \multirow[b]{2}{*}{ Yield $\left(\mathrm{g} \mathrm{kg}^{-1}\right)$} & \multicolumn{8}{|c|}{ Cell wall sugars (mol \%) } & \multirow[b]{2}{*}{ Total sugars $\left(\mathrm{g} \mathrm{kg}^{-1}\right)$} \\
\hline & & & Rha & Fuc & Ara & Xyl & Man & Gal & Glc & UrAc & \\
\hline \multirow[t]{3}{*}{ Raw } & SDS & 20.6 & 8 & - & 18 & $\operatorname{tr}$ & - & 6 & 45 & 23 & 381 \\
\hline & PrAW & 8.9 & 4 & - & 5 & - & - & 1 & 10 & 80 & 22 \\
\hline & CWM & 91.4 & 1 & - & 14 & 22 & 3 & 3 & 43 & 14 & 379 \\
\hline \multirow[t]{3}{*}{ Dry-salted } & SDS & 25.0 & 6 & - & 24 & - & - & 6 & 29 & 34 & 417 \\
\hline & PrAW & 1.1 & 3 & - & 2 & - & 1 & 1 & 55 & 37 & 120 \\
\hline & CWM & 83.6 & 1 & - & 9 & 19 & 3 & 2 & 46 & 20 & 357 \\
\hline
\end{tabular}

Yield is expressed in $\mathrm{g}$ dry weight material per kg dried olive pulp.

tr, trace amount. 
rise to ten distinct fractions that were analyzed separately, but the data were condensed into seven major extracts: (1) imidazole; (2) $\mathrm{Na}_{2} \mathrm{CO}_{3}$; (3) $0.5 \mathrm{~mol} \mathrm{~L}-1 \mathrm{KOH}$; (4) $1 \mathrm{~mol} \mathrm{~L}^{-1} \mathrm{KOH}$; (5) $4 \mathrm{~mol}$ $\mathrm{L}^{-1} \mathrm{KOH}$; (6) sn-CR; and (7) cellulosic residue. Table 3 shows the amount of polymeric material and the sugar composition of each extract for both olive samples.

The total polymeric material recovered from the CWM of raw olives $(65.5 \%)$ was considerably lower than that of the dry-salted olives $(83.8 \%)$. Together with the data discussed in the previous section, this result suggests that, in spite of some solubilization of polymeric material during processing, the polymers remaining in the cell walls of these olives were stabilized, resulting in minor losses during the dialysis steps. In general, the polymeric material extracted from the processed olives with aqueous solutions was poorer in carbohydrates than that obtained from the raw olives. Imidazole and carbonate solutions solubilized predominantly pectic polysaccharides, as these extracts were rich in UrAc, Ara and also contained Rha and Gal in minor amounts. According to the literature, ${ }^{18}$ the pectic polysaccharides found in imidazole extracts were less ramified than those solubilized by carbonate. The respective UrAc/Ara ratio was approximately 1.4 and 0.7 . However, in opposition to that reported for Douro olives, ${ }^{18,29}$ the imidazole extracts of Thasos olives also contained high proportions of $\mathrm{Glc}$ and $\mathrm{Xyl}$, showing that hemicelluloses have been solubilized together with pectic polymers.

In general, the pectic polysaccharides solubilized from the CWM of dry-salted olives had less Ara content. Data from Table 3 show that the UrAc/Ara ratio in the imidazole and carbonate extracts of drysalted olives is 2.4 times higher than that of the raw olives. These results agree with the corresponding CWM composition, as discussed above. Moreover, the sugar content of the imidazole + carbonate extracts expressed on a mg per fruit basis (Fig. 1(a)) showed that the total amount of polysaccharides recovered in these two fractions was lowest in the dry-salted olives, which is consistent with the lower polysaccharide content found in the CWM of that sample. This affected all the pectic polysaccharides, as the amount of Ara, UrAc, Gal and Rha diminished. The more pronounced decrease in Ara content compared to that observed for UrAc indicates that the increase in the UrAc/Ara ratio of imidazole and carbonate extracts was a consequence of the preferential loss of Ara-rich pectic polysaccharides during dry-salting processing.

The total amount of polysaccharides recovered in $\mathrm{KOH}$ extracts was not significantly diminished by processing (Fig. 1(b)). For raw olives, about 50\% of that material was solubilized in alkali solutions of 0.5 and $1 \mathrm{~mol} \mathrm{~L}^{-1}$. The sugar composition of these extracts (Table 3) showed that they were mainly composed of glucuronoxylans and xyloglucans and minor amounts of pectic polysaccharides. As mentioned by other

Table 3. Sugar composition of fractions of cell wall material from raw and dry-salted olive pulp obtained by sequential extraction with aqueous solvents

\begin{tabular}{|c|c|c|c|c|c|c|c|c|c|c|c|}
\hline \multirow[b]{2}{*}{ Fraction } & \multirow[b]{2}{*}{ Sample } & \multirow[b]{2}{*}{ Yield $^{\mathrm{a}}(\%)$} & \multicolumn{8}{|c|}{ Cell wall sugars (mol\%) } & \multirow[b]{2}{*}{ Total sugars $\left(\mathrm{g} \mathrm{kg}^{-1}\right)$} \\
\hline & & & Rha & Fuc & Ara & Xyl & Man & Gal & Glc & UrAc & \\
\hline \multicolumn{12}{|l|}{ Imidazole } \\
\hline & Raw & 0.8 & 3 & $\operatorname{tr}$ & 23 & 13 & 3 & 4 & 21 & 32 & 533 \\
\hline & Dry-salted & 1.2 & 1 & - & 10 & 12 & 5 & 2 & 35 & 34 & 190 \\
\hline \multicolumn{12}{|l|}{$\mathrm{Na}_{2} \mathrm{CO}_{3}$} \\
\hline & Raw & 2.4 & 4 & $\operatorname{tr}$ & 48 & 1 & $\operatorname{tr}$ & 6 & 7 & 34 & 530 \\
\hline & Dry-salted & 3.6 & 2 & - & 31 & $\operatorname{tr}$ & - & 2 & 12 & 53 & 250 \\
\hline \multicolumn{12}{|c|}{$0.5 \mathrm{~mol} \mathrm{~L}^{-1} \mathrm{KOH}$} \\
\hline & Raw & 1.2 & - & 1 & 12 & 44 & 1 & 7 & 27 & 10 & 790 \\
\hline & Dry-salted & 2.4 & 2 & - & 8 & 37 & 2 & 5 & 31 & 15 & 483 \\
\hline \multicolumn{12}{|c|}{$1 \mathrm{~mol} \mathrm{~L}^{-1} \mathrm{KOH}$} \\
\hline & Raw & 3.6 & 1 & 1 & 12 & 38 & 5 & 8 & 26 & 9 & 681 \\
\hline & Dry-salted & 5.6 & 1 & $\operatorname{tr}$ & 7 & 27 & 8 & 7 & 29 & 21 & 492 \\
\hline \multicolumn{12}{|c|}{$4 \mathrm{~mol} \mathrm{~L}^{-1} \mathrm{KOH}$} \\
\hline & Raw & 9.3 & 2 & $\operatorname{tr}$ & 13 & 16 & 18 & 10 & 26 & 14 & 344 \\
\hline & Dry-salted & 12.1 & $\operatorname{tr}$ & - & 7 & 15 & 19 & 8 & 30 & 21 & 227 \\
\hline \multicolumn{12}{|l|}{ sn-CR } \\
\hline & Raw & 1.1 & 3 & - & 52 & 2 & - & 7 & - & 35 & 821 \\
\hline & Dry-salted & 0.8 & 2 & - & 47 & 2 & - & 3 & 4 & 42 & 307 \\
\hline \multicolumn{12}{|l|}{ CR } \\
\hline & Raw & 47.3 & $\operatorname{tr}$ & - & 13 & 21 & 1 & 1 & 51 & 12 & 482 \\
\hline & Dry-salted & 58.1 & $\operatorname{tr}$ & - & 6 & 24 & 1 & 1 & 51 & 17 & 450 \\
\hline
\end{tabular}

a Yield is expressed as a percentage of CWM.

tr, trace amount. 
(a)

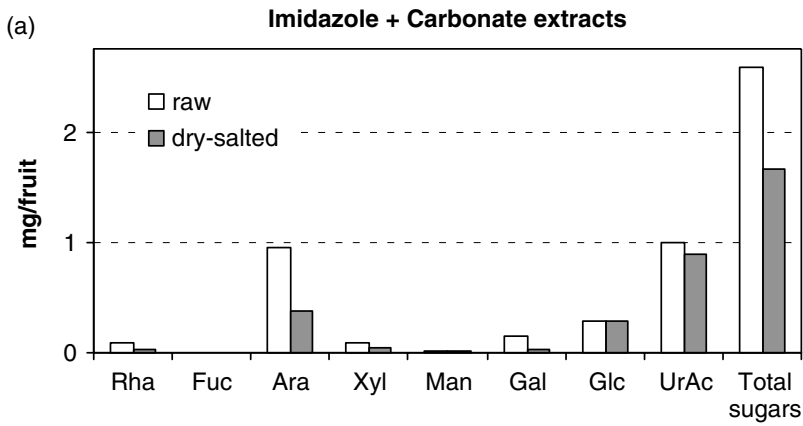

(b)



(c)

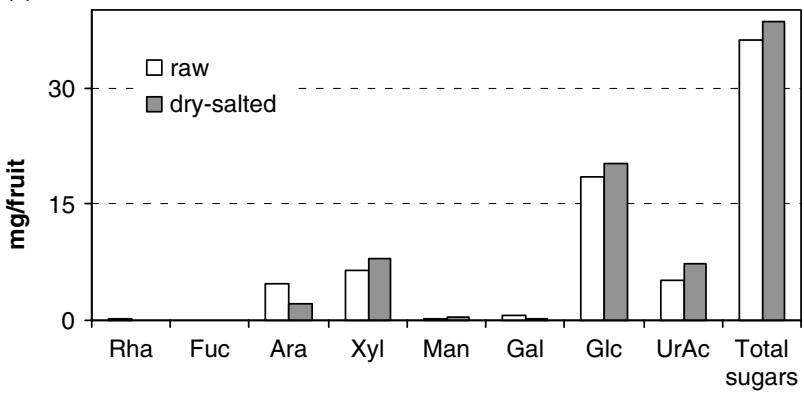

Figure 1. Sugar composition (expressed in mg per fruit) of CWM extracts for raw and dry-salted olives: (a) imidazole + carbonate extracts; (b) $\mathrm{KOH}$ extracts; (c) sn-CR and cellulosic residue.

authors, the occurrence of xylans can be inferred by the presence of Xyl in relatively higher amounts than Glc. In olive pulp, these polysaccharides occur as glucuronoxylans. ${ }^{24,30}$ The occurrence of xyloglucans was assumed by the presence of Glc, Gal and traces of Fuc, beyond Xyl, as mentioned in the literature. ${ }^{31,32}$ Pectic polysaccharides in these extracts were also detected, owing to the presence of Ara, UrAc, Gal and Rha.

The $4 \mathrm{~mol} \mathrm{~L}^{-1} \mathrm{KOH}$ solution also solubilized glucuronoxylans, xyloglucans and pectic polysaccharides. However, these extracts were richer in (gluco)mannans, as inferred by the higher proportion of Man. Data from Table 3 show that, in general, polysaccharides solubilized from raw olives by $\mathrm{KOH}$ solutions had lower UrAc and Glc and higher Ara and Xyl proportions than those obtained from dry-salted olives. In Fig. 1(b), the most noticeable differences in $\mathrm{KOH}$ soluble sugars were observed in UrAc (increase of $58 \%$ ) and Ara (decrease of $48 \%$ ) amounts, indicating that, with respect to the alkali-soluble material, pectic polysaccharides were primarily affected by the dry-salting.
The yield of cell wall polysaccharides that remained in the alkali-extracted residue was not substantially affected by processing, although slightly more polysaccharides were recovered in these extracts from the processed olive fruit (Fig. 1(c)). For both olive samples, Glc was the main sugar in the $\mathrm{KOH}$ residue. This was mainly from cellulosic origin, as the non-cellulosic Glc only accounted for $5 \%$ and $7 \%$ of the total Glc in raw and dry-salted cellulosic residue, respectively. These residues still contained glucuronoxylans, xyloglucans and pectic polysaccharides that are highly entangled in the cellulose matrix. ${ }^{18}$ The high polysaccharide content found in the cellulosic residue of processed olives could be partially explained by the retention of some hemicellulosic material in the cell walls of the dry-salted olives, since a high content of $\mathrm{Xyl}$ and Glc was noted. Moreover, as described for the $\mathrm{KOH}$-soluble extracts, the main changes in the sugar content were observed in UrAc (increase of $40 \%$ ) and Ara (decrease of $53 \%$ ) contents, indicating that even for the high entangled polysaccharides in the cellulosic matrix the pectic polymers are preferentially influenced by dry-salting. This result, together with the previously discussed data, suggests that the dry-salting process of Thasos olives can affect the composition of pectic polysaccharides all along the cell wall of the fruit.

As described by Coimbra et al., ${ }^{18}$ the separation of the supernatant obtained after neutralization and dialysis of the alkali extracted residue (sn-CR) allowed the recovery of arabinan-rich pectic polysaccharides (Table 3). Dry-salting processing decreased the total amount of polysaccharides in the sn-CR extract, as also the relative amount of Ara. The UrAc/Ara ratio varied from 0.7 to 0.9 , respectively, for the raw and processed olives. The major differences in the polysaccharide composition obtained in residues after alkali treatment were found in the pectic polysaccharides still entangled in the cellulosic material, as the proportion of UrAc to Ara varied from 1:1 in raw olives to $1: 3$ in dry-salted olives (Table 3).

\section{Changes in cell wall polysaccharides with processing}

Cell wall polysaccharides were estimated using all the data from the extracts resulting from CWM preparation and sequential extraction, as described in the Experimental section. The results of polysaccharide composition on a fruit basis for raw and dry-salted olives are presented in Table 4. These data show that the total amount of polysaccharides recovered was not much affected by processing, although the slight increase observed seems to be mainly determined by changes in pectic polysaccharides. Higher amounts of galacturonans and lower amounts of arabinans were found in the pectic polysaccharides after processing, suggesting that dry-salting with coarse sodium chloride stabilized the galacturonan-rich pectic polymers, resulting in minor losses even when dialyzed, as compared to 
Table 4. Olive pulp cell wall polysaccharide composition of raw and dry-salted olive pulp of Thasos

\begin{tabular}{lcc}
\hline & Raw & Dry-salted \\
\hline Pectic polysaccharides & 23 & 25 \\
Galacturonan & $(10)$ & $(15)$ \\
Arabinan & $(9)$ & $(7)$ \\
Glucuronoxylan & 9 & 10 \\
Xyloglucan & 13 & 13 \\
Mannan & 1 & 2 \\
Ara-rich glycoprotein & tr & tr \\
Cellulose & 18 & 19 \\
Total polysaccharides & 64 & 69 \\
\hline
\end{tabular}

Values are expressed as mg per fruit.

Values between parentheses are part of pectic polysaccharides. tr, trace amount.

losses that occurred in the extracted material from raw olives. It is possible that sodium can improve the stabilization of these polysaccharides in the cell walls by reducing the electrostatic repulsion of their acidic groups, as previously suggested. ${ }^{3}$ Conversely, dry-salting provoked higher solubilization of the Ararich polymers, resulting in a lower recovery of these polysaccharides. According to the data discussed above, these polymers were partially solubilized to the soaking medium, although the hypothesis of additional losses during dialyses cannot be rejected.

\section{Concluding Remarks}

To our knowledge, this is the first report focusing on the influence of dry-salt processing on the texture and cell wall composition of olive fruits. Characterization of the mechanical properties of olives of the Thasos variety was performed using the skin and the flesh, in order to understand the contribution of each tissue to the global texture of the fruit, and to evaluate the influence of processing. The results demonstrated that dry-salt processing mainly affected the textural characteristics of the flesh. The strength of the flesh increased approximately 4.5 times, and became more deformable to failure and stiffer. The extensive characterization of the cell wall polysaccharides showed that dry-salting increased the cell wall solubilization of Ara-rich pectic polysaccharides, but stabilized galacturonan-rich polymers, possibly by reducing their electrostatic repulsion. Thus, the observed textural improvement of dry-salted Thasos olives must be associated with reorganization of galacturonan-rich pectic polysaccharides in the cell walls of the fruit.

\section{Acknowledgements}

The authors are grateful for the financial support of the EU Project OLITEXT FAIR CT97-3053 and FCT for funding the Research Unit 62/94 'Química Orgânica, Produtos Naturais e Agro-Alimentares'. The authors also acknowledge the support of the UK
BBSRC. Thanks are also due to Dr Constantinos Z Katsaboxakis from ITAP, Athens, Greece, for providing the samples.

\section{References}

1 Panagou EZ, Tassou CC and Katsaboxakis KZ, Microbiological, physicochemical and organoleptic changes in dry-salted olives of Thassos variety stored under different modified atmospheres at 4 and $20^{\circ} \mathrm{C}$. Int $\mathcal{F}$ Food Sci Technol 37:635-641 (2002).

2 Panagou EZ, Greek dry-salted olives: monitoring the dry-salting process and subsequent physico-chemical and microbiological profile during storage under different packing conditions at 4 and $20^{\circ}$ C. LWT-Food Sci Technol 39:322-329 (2006).

3 Jiménez A, Heredia A, Guillén R and Fernández-Bolãnos J, Correlation between soaking conditions, cation content of cell wall, and olive firmness during 'Spanish green olive' processing. F Agric Food Chem 45:1653-1658 (1997).

4 Jiménez A, Guillén R, Sánchez C, Fernández-Bolãnos J and Heredia A, Changes in texture and cell wall polysaccharides of olive fruit during 'Spanish green olive' processing. F Agric Food Chem 43:2240-2246 (1995).

5 Georget DMR, Smith AC, Waldron KW and Rejano L, Effect of 'Californian' process on the texture of Hojiblanca olive (Olea europaea L.) harvested at different ripening stages. $7 \mathrm{Sci}$ Food Agric 83:574-579 (2003).

6 Tassou CC, Katsaboxakis CZ, Georget DMR, Parker ML, Waldron KW, Smith AC, et al, Effect of calcium chloride on mechanical properties and microbiological characteristics of cv. Conservolea naturally black olives fermented at different sodium chloride levels. F Sci Food Agric 87:1123-1131 (2007).

7 Van Buren JP, The chemistry of texture in fruits and vegetables. f Texture Stud 10:1-23 (1979).

8 Plat D, Ben-Shalom N, Levi A, Reid D and Goldschmidt E, Degradation of pectic substances in carrots by heat treatment. F Agric Food Chem 36:362-365 (1988).

9 Van Buren JP, Kean WP and Wilkison M, Influence of salts and $\mathrm{pH}$ on the firmness of cooked snap beans in relation to the properties of pectin. 7 Texture Stud 19:15-25 (1988).

10 Marsilio V, Lanza B and De Angelis M, Olive cell wall components: physical and biochemical changes during processing. I Sci Food Agric 70:35-43 (1996).

11 Marsilio V, Lanza B, Campestre C and De Angelis M, Ovendried table olives: textural properties as related to pectic composition. I Sci Food Agric 80:1271-1276 (1996).

12 Jiménez A, Guillén R, Sánchez C, Fernández-Bolãnos J and Heredia A, Molecular weight and ionic characteristics of olive cell wall polysaccharides during processing. 7 Agric Food Chem 44:913-918 (1996).

13 Mafra I, Barros AS and Coimbra MA, Effect of black oxidising table olive process on the cell wall polysaccharides of olive pulp (Olea europaea L. var. Negrinha do Douro). Carbohydr Polym 65:1-8 (2006).

14 Mafra I, Barros AS and Coimbra MA, The combined effects of black oxidising table olive process and ripening on the cell wall polysaccharides of olive pulp. Carbohydr Polym 68:647-657 (2007).

15 Marsilio V, Campestre C, Lanza B and De Angelis M, Sugar and polyol compositions of some European olive fruit varieties (Olea europaea L.) suitable for table olive purposes. Food Chem 72:485-490 (2001).

16 Bianco A and Uccella N, Biophenolic components of olives. Food Res Int 33:475-485 (2000).

17 Bastoni L, Bianco A, Piccioni F and Uccella N, Biophenolic profile in olives by nuclear magnetic resonance. Food Chem 73:145-151 (2001).

18 Coimbra MA, Delgadillo I, Waldron KW and Selvendran RR, Isolation and analysis of cell wall polymers from olive pulp, in Modern Methods of Plant Analysis, Vol. 17, ed. by Linskens H-F and Jackson JF. Springer, Berlin, pp. 19-44 (1996). 
19 Mafra I, Lanza B, Reis A, Marsilio V, Campestre C, Angelis M, et al, Effect of ripening on texture, microstructure and cell wall polysaccharide composition of olive fruit. Physiol Plantarum 111:439-447 (2001)

20 Selvendran RR, March JF and Ring SG, Determination of aldoses and uronic acid content of vegetable fiber. Anal Biochem 96:282-292 (1979).

21 Blakeney AB, Harris PJ, Henry RJ and Stone BA, A simple and rapid preparation of alditol acetates for monosaccharide analysis. Carbohydr Res 113:291-299 (1983).

22 Harris PJ, Blakeney AB, Henry RJ and Stone BA, Gas chromatographic determination of the monosaccharide composition of plant cell wall preparations. F AOAC Int 71:272-275 (1988)

23 Blumenkrantz $\mathrm{N}$ and Asboe-Hansen G, New method for quantitative determination of uronic acids. Anal Biochem 54:484-489 (1973).

24 Coimbra MA, Waldron KW and Selvendran RR, Isolation and characterization of cell wall polymers from olive pulp (Olea europaea L.). Carbohydr Res 252:245-262 (1994).

25 Coimbra MA, Waldron KW, Delgadillo I and Selvendran RR, Effect of processing on cell wall polysaccharides of green table olives. F Agric Food Chem 44:2394-2401 (1996).
26 Coimbra MA, Barros A, Rutledge DN and Delgadillo I, FTIR spectroscopy as a tool for the analysis of olive pulp cell-wall polysaccharide extracts. Carbohydr Res 317:145-154 (1999).

27 Georget DMR, Smith AC and Waldron KW, Effect of ripening on the mechanical properties of Portuguese and Spanish varieties of olive (Olea europaea L). $\mathcal{F}$ Sci Food Agric 81:448-454 (2001).

28 Agar IT, Hess-Pierce B, Sourrour MM and Kader AA, Quality of fruit and oil of black-ripe olives is influenced by cultivar and storage period. F Agric Food Chem 46:3415-3421 (1998).

29 Mafra I, Efeito do amadurecimento e processamento nos polissacarídeos das paredes celulares da polpa da azeitona. PhD thesis, Universidade de Aveiro, Aveiro (2002).

30 Gil-Serrano A and Tejero-Mateo P, A xyloglucan from olive pulp. Carbohydr Res 181:278-281 (1988).

31 Gil-Serrano A, Mateos-Matos MI and Tejero-Mateo P, Acidic xylan from olive pulp. Phytochemistry 25:2653-2654 (1986).

32 Coimbra MA, Rigby NM, Selvendran RR and Waldron KW, Investigation of the occurrence of xylan-xyloglucan complexes in the cell walls of olive pulp (Olea europaea). Carbohydr Polym 27:277-284. 